\title{
Działalność szkoły brackiej w Mińsku od II połowy XVI wieku do XVIII wieku*
}

\author{
Marcin Mironowicz \\ Wydział Historyczno-Socjologiczny, Uniwersytet w Białymstoku \\ Polska \\ marcin.mironowicz5@gmail.com
}

M. Mironowicz, Activities of brotherhood's school in Minsk in the second half of 16th century to 18th century, Elpis, 20 2018: 79-84.

\begin{abstract}
Article describes history of brotherhood's school in Minsk in 16th-18th century, from beginnings of school located in castle's church of the Most Holy Virgin Marry to situated in monastery of saints Peter and Paul. Together with activities of brotherhood's school, was described activity of church's brotherhood in wider range - struggle for preservation of identity against increasingly in force Union.
\end{abstract}

\begin{abstract}
Streszczenie: Artykuł omawia historię szkoły brackiej w Mińsku w XVI-XVIII w. od jej kolebki przy cerkwi zamkowej NMP do usytuowanej przy monasterze św. św. Piotra i Pawła. Na tle działalności szkoły brackiej poruszona została działalność bractwa cerkiewnego w szerszym aspekcie - walki o zachowanie tożsamości w obliczu wrastającej w siłę unii.
\end{abstract}

Keywords: Orthodox church, orthodox brotherhoods, brotherhood's school, Minsk

Słowa kluczowe: Kościół prawosławny, bractwa cerkiewne, szkoła bracka, Mińsk

W Mińsku w końcu XVI wieku, przed przyjęciem unii, funkcjonowało 10 cerkwi i jeden kościół katolicki ${ }^{1}$. Źródła odnotowują, że przy monasterskiej cerkwi św. św. Kosmy i Damiana do końca XVI wieku prowadzona była szkoła ${ }^{2}$. Najstarsze bractwo prawosławne w Mińsku działało przy cerkwi zamkowej pw. Narodzenia NMP, która zbudowana została na gruntach należących do Janusza Radziwiłła. Dnia 11 września 1592 roku bractwo to otrzymało przywilej od króla Zygmunta III, w którym nadano mu prawo na zbudowanie i prowadzenie szpitala, domu brackiego i szkoły. Szpital dla ludzi ubogich i chorych zajmował szczególne miejsce $\mathrm{w}$ działalności brackiej, dlatego bractwo określano mianem „bractwa szpitalnego". Fundusze na działalność statutową konfraternia pozyskiwała z zapisów testamentowych i fundacyjnych, a także z sycenia miodu. Przywilej królewski pozwalał bractwu sycić i sprzedawać miód cztery razy w roku: na Wielkanoc, św. Piotra, św. Archanioła Michała i zapusty (wg starego kalendarza). Uzyskane pieniądze przeznaczano na potrzeby cerkwi i prowadzenie szpitala. Monarcha w przywileju dał również zgodę na zbudowanie i prowadzenie szkoły brackiej „для науки дътокъ малыхъ школу мъти и бакаляра въ ней ховати и тамъ дътей письма Греческого и Руского учити давати"’. Źródła milczą na

\footnotetext{
* Praca naukowa finansowana ze środków budżetowych na naukę w latach 2015-2018 jako projekt badawczy w ramach programu pod nazwą „Diamentowy Grant”.

Р. В. Баравой., Менскія церквы, [в:] Вялікае княства Літоўскае. Эниіклапедыя, Т. 2, Мінск 2006, с. 299-300.

2 Tamże, c. 299.

$3 A 3 P$, т. 4, нр. 36, с. 53-54; В.П. Мещеряков, Братские школь Бело-
}

temat działalności szkoły, chociaż bractwo wspomina się w królewskim dyplomie z 1601 roku. Przywilej skierowany był do ratusza miejskiego i upominał władze Mińska, aby nie przeszkadzały w budowie brackiego młyna, dzięki któremu stowarzyszenie mogło zwiększyć środki przeznaczone na utrzymanie szpitala: „для поратованя попатрения менованого шпиталя и пожывеня внем уломъныхъ людеи недолужныхъ"4. Cerkiew Preczystenskaja była jedyną świątynią prawosławną w Mińsku po przyjęciu unii brzeskiej. Większość prawosławnych mińszczan wypisywało się ze swoich dotychczasowych, już unickich, parafii i stawało się parafianinami cerkwi Narodzenia NMP5 . Bez wątpienia ten stan rzeczy mógł istnieć dzięki protekcji żony Janusza Radziwiłła Zofii Olelkowicz Słuckiej. Czy jest dziełem przypadku, że w 1612 roku, tj. roku śmierci Zofii Słuckiej, powstało nowe bractwo przejmujące na siebie obowiązek ochrony prawosławia w Mińsku? Jeszcze w 1613 roku Januszowi Radziwiłłowi udało się ochronić świątynię od przejęcia przez unickie duchowieństwo. W 1614 roku magnat wyraził zgodę na przebywanie tu mniszek. Jednak i one, podobnie jak wcześniej prawosławni mińszczanie, wkrótce znalazły schronienie w nowym monasterze brackim św. św. Piotra i Pawła ${ }^{6}$.

рссии (ХVI- первая половина ХVII в.), Минск 1977, с. 18;

4 Собрание древних грамот и актов городов Минской губернии, нр. 42 , с. 67-68.

5 Ю. М. Мікульскі, Гісторыя іконы Божай Маці Менскай (да XVIII cm.), „Беларуская даўніна”, Мінск 2014, с. 86-87.

6 Р. В Баравой., Менскія иерквы, с. 300. W 1622 roku cerkiew Narodzenia NMP spłonęła. Krzysztof Radziwiłł czynił starania w celu jej odbudowy, jednak brak informacji źródłowych na ten temat. 
W 1616 roku, kiedy Atanazy Pokosta, miński archimandryta unicki, chciał uzyskać w magistracie informację o ,szpitalnym bractwie”, otrzymał od burmistrzów odpowiedź, że „всльдствіе раздоровъ оно прекратило свое сушествованіе" i nikt nie wiedział czy ono jeszcze funkcjonowało. Unici wykorzystali ten fakt i wyprosili u króla przywilej na majątek bracki i zawładnęli nim? ${ }^{7}$.

Szpital w końcu XVI wieku prowadziło również bliżej nieznane bractwo przy cerkwi Woskresienskiej ${ }^{8}$.

W 1612 roku powstało w Mińsku nowe bractwo, w skład którego obok mieszczan weszła szlachta różnych województw i powiatów Wielkiego Księstwa Litewskiego9. Bractwo działało przy monasterze św. św. Piotra i Pawła. Z przywileju Władysława IV z 18 marca 1633 roku wynika, że było ono kontynuatorem bractwa ,szpitalnego". W dokumencie odnotowano: ,przywilejem naszym waruiemy to, iż iak cerkiew narodzenia przeczystey Bohorodicy, zdawna z szpitalem w possessyi ich będąca (...) przy tym bractwie (...) zostawać ma wiecznymi czasy"10. W 1611 roku Bohdanowa Stetkiewiczowa przekazała trzy place, na których miał być zbudowany bracki monaster i cerkiew św. św. Piotra i Pawła ${ }^{11}$. W akcie fundacyjnym zapisano „Млсти в Менску на кгунтех нашых шляхецких под волностстью и правом нашым шлахецким будучих и от нас шляхты фундованых збудовалисмы (...) анапамет светых верховных Апостол Петра и Павла црков и манастыр”. W dokumencie zaznaczono, że „для помноженя фалы Божое для твиченя внеи детокъ и для оздобы тои церкви заложылисмо и внеи людеи учоных ховати одностаине позволилисмо ${ }^{12}$. Dokument został podpisany przez 52 osoby, w tym Bohdana Ogińskiego, Jana Ogińskiego, Aleksandra Ogińskiego, Aleksandra Tryznę, Adama Tryznę, Grzegorza Wołodkowicza, Jarosza Wołodkowicza, Iwana Rohozę, Stefana Rohozę, Bohdana Stetkiewicza, Jana Stetkiewicza, Jerzego Skumina-Tyszkiewicza $^{13}$. W 1613 roku Bohdanowa Stetkiewiczowa wy-

К. Харламповичъ, Западнорусскія православныя школьл.., с. 335; Собрание древних грамот и актов городов Минской губернии, православных монастырей, иерквей и по разным предметам, Минск 1848, нр-ы 42, 54, 56, 68.

8 Potwierdzenie testamentu mieszczanki mińskiej Waruszy Jewcukowny z 19 maja 1599 roku, która zapisała dwa domy z ogrodami w Mińsku na dwa szpitale - prowadzone przez bractwo soborne i woskresienskie. Собрание древних грамот и актов городов Минской губернии, нр 83, c. $150-156$.

9 W Rejestrze dokumentów, funduszów, testamentów, praw, wieczystych zapisów od różnych fundatorów na cerkiew SS. Apostołów Piotra i Pawła sporządzonym 29 stycznia 1792 roku w fascykule pierwszym pod pozycją czwartą zapisano „1612. Indykta 10 datowany, a 1617 Ianuara 13 dnia w Ziemi Mińskiej attykowany Widymus Funduszu od szlachty różnych województwa y powiatów do Bractwa Mińskiego przy Cerkwi SS. Piora i Pawła wpisanych wyrażający: że na swych szlacheckich placach Cerkiew i Klasztor SS. Apostołów Piotra i Pawła zbudowali i Szkołę założyli”. LVIA, f. 610, nr 3, 369, k. 1, k 3-3v.

${ }_{10} A B A K$, т. XI, нp. 36 , c. 103.

11 LVIA, f. 610, nr 3, 369, k. 1.

12 Собрание древних грамот и актов городов Минской губернии, нр 65 , c. $111-115$.

13 W 1623 roku sędzia ziemski miński Marcin Wołodkowicz wraz z żoną Dorotą Dorohostajską ufundowali na rzecz monasteru św. św. Piotra i Pawła i bractwa przy nim działającego folwark o nazwie Perespa. LVIA, f. 610, nr 3, 369, k. 2; Собрание древних грамот и актов mogła, aby klasztor miński przyjął zwierzchność klasztoru wileńskiego św. Ducha ${ }^{14}$. Tym samym monaster i działające przy nim bractwo zostało uniezależnione od unickich hierarchów. Monaster św. Ducha w Wilnie wysłał do nowego klasztoru mnichów, wśród których znalazł się bliski współpracownik Leoncjusza Karpowicza Paweł Domżyw. Spełniając wolę fundatorki objął on funkcję pierwszego ihumena monasteru św. św. Piotra i Pawła organizując życie monastyczne ${ }^{15}$. Początkowo budynki klasztorne, w tym cerkiew, były drewniane i wznoszono je od końca 1611 roku do 1613 roku. W latach dwudziestych XVII wieku cerkiew św. św. Piotra i Pawła była murowaną, a jej ściany ozdabiały freski ${ }^{16}$. Przy monasterze brackim w Mińsku w 1619 roku ufundowano też klasztor żeński ${ }^{17}$.



D. Strukov, Cerkiew św.św. Piotra i Pawła w Mińsku przed przebudowa $w$ XIX w. Rycina z 1864 roku ze zbiorów Biblioteki Uniwersyteckiej $w$ Wilnie

городов Минской губернии, нр. 81, с. 145-147. Działalność monasteru brackiego wsparli m. in.: w 1616 roku trzy place ufundował Jarosz Jaroszewicz Żyżemski; w 1616 roku grunty, place i łąkę zapisał Iwan Tkacz; Mikołaj Woroniec w 1622 roku zapisał dwie sianożęci; Adam Wańkowicz, wojski miński w swym testamencie 100 kop groszy litewskich w 1635 roku; Собрание древних грамот и актов городов Минской губернии, нр. 104, с. 202; łąkę w 1638 podarowała Agata Miechliczowa; w 1638 roku dom podarował Wasyl Wołowicz; dwa place w Mińsku w 1643 roku podarowali Krzysztof i Katarzyna Kiszkowie; w 1652 roku Kasia Kościuszkowa przekazała łąkę; w 1658 roku Luba Priwalniowa zapisała w testamencie plac; w 1660 roku Fiodor Jeftuchowicz zapisał w testamencie plac, Собрание древних грамот и актов городов Минской губернии, нр. 128 , с. 275 , w testamencie uczynił zapis na plac w 1660 roku Piotr Popowicz; dwa place podarowali w 1667 roku Damian Michajłowicz i Grzegorz Łoszakiewicz; pół placu i niwę zapisała w testamencie w 1679 Katarzyna Siemionowa Bohdanowiczowa. LVIA, f. 610, nr 3, 369, k. 1-1y

14 LVIA, f. 610, nr 3, 369, k. 1.

15 Собрание древних грамот и актов городов Минской губернии, нр. 69 , с. 121.

16 Azarija, ihumen monasteru św. Ducha w Wilnie, w liście do metropolity kijowskiego Arseniusza Mohylańskiego z dnia 16 lipca 1766 roku pisał o cerkwi św. św. Piotra i Pawła: „церковь большая мурованая и все было внутри малиованная”, Минские епариальные ведомости , 1892, нр. 11, с. 310. Zob. Баравой Р. В., Агляд гісторыі мінскага свята-петра-пайлаўскага сабора і манастыра ( ХVII - пачатак XX cmcm.), [в:] Верныя веры баџькоў, Мінск 2013, с. 190-192; Ф. А. Сарока, Пра рэставраиыю насиенных роспісай, [в:] Верныя веры баџькоў, Мінск 2013, c. 228-229.

17 W 1614 roku Janusz Radziwiłł zezwolił prawosławnym mniszkom budować się i mieszkać przy cerkwi Narodzenia NMP. LVIA, f. 610, nr 3,369, k. 1v. W 1618 roku zakonnice otrzymały błogosławieństwo ihumena monasteru św. Ducha w Wilnie Leoncjusza Karpowicza na budowę monasteru żeńskiego przy monasterze św. św. Piotra i Pawła w Mińsku. Собрание древних грамот и актов городов Минской губернии, нр. 64, c. 109-110. W 1619 roku Anna z Ogińskich Stetkiewicz ustanowiła mniszkom fundusz na dom i plac mniszkom mieszkającym przy monasterze św. św. Apostołów Piotra i Pawła, LVIA, f. 610, nr 3, 369, k. 1v.; Собрание древних грамот и актов городов Минской губернии, нр. 70, c. 123-127. W 1624 roku żeński klasztor w Mińsku otrzymał błogosławieństwo metropolity kijowskiego Hioba Boreckiego. Собрание древних грамот и актов городов Минской губернии, нр. 82, с. 147-149. 
Szkoła bracka ulokowana była przy cerkwi św. św. Piotra i Pawła. Uczęszczali do niej chłopcy z rodzin szlacheckich i mieszczańskich z Mińska i okolic. Niektórzy zamieszkiwali w bursie na terenie monasteru. W 1617 roku w szkole brackiej nauczało kilku bakalarzy wywodzących się spośród mnichów. Świadczy o tym zapis w skardze ihumena Gedeona umieszczony w księgach grodzkich mińskich w 1617 roku: „Законников яко Бакаларовъ и хлопят при той церкви мешкаючих"18.

W Mińsku nie było szkół katolickich, ale funkcjonowały unickie. Za wiedzą i przyzwoleniem zakonników unickich i ich nauczycieli, chcących odstraszyć od prawosławia lub pozyskać do swej placówki oświatowej chłopców prawosławnych, uczniowie wyznania unickiego doprowadzali do bójek z uczniami szkoły brackiej. Przykładem odnotowanym w źródłach są napady chłopców uczących się w szkole unickiej przy cerkwi św. św. Kosmy i Damiana na dzieci uczęszczające do szkoły brackiej. Taki napad wydarzył się m. in. 16 lutego 1617 roku. Kilkudziesięciu wyrostków ze szkoły unickiej, za wiedzą swych nauczycieli, napotykając uczniów szkoły brackiej „били, мордовали, и окрутне паствечися над ними мало на смерть не позабияли". W zajściu ucierpiało 11 chłopców ${ }^{19}$. Skargę do sądu grodzkiego wniósł ihumen, a zarazem rektor szkoły brackiej Gedeon 24 lutego 1617 roku$^{20}$.

Szkoła bracka w Mińsku od początku swej działalności była jedną z głównych przyczyn niezgody między prawosławnych i unitami. Unici wykorzystywali wszystkie nadarzające się możliwości, aby doprowadzić do jej zamknięcia. 27 listopada 1619 prawosławna szlachta i obywatele Litwy protestowali przeciwko zamiarom Piotra Tyszkiewicza (1571-1631), wojewody mińskiego, który chciał zamknąć „церковъ и манастыр светых апостол петра и павла и школы при неи на грунтех стародавных шляхецких (...) знести и волного уживаня набоженъства всем станомъ тое релии заборонит" 21 . Wkrótce nad szkołą zawisło nowe niebezpieczeństwo. Wikariusz unickiego metropolity kijowskiego Józefa Welamina Rutskiego w Mińsku Hilarion Baranowicz skierował do króla skargę o to, że bractwo mińskie podżegało naród przeciwko unii, pozyskiwało nowe grunty wykorzystując do tego szlachtę, budowało na tych gruntach świątynie, dawało schronienie mnichom usuniętym z innych monasterów, o przejęcie cerkwi zamkowej Narodzenia NMP wraz ze szkołą, o uczestnictwo w schadzkach ludzi z innych ośrodków prawosławnych,

\footnotetext{
18 Собрание древних грамот и актов городов Минской губернии, нр. 62, с. 105; К. Харламповичъ, Западнорусскія православныя школьл..., c. 336 .

19 Wśród poszkodowanych znaleźli się: Fiodor Tomicz, Jakub Aleksandrowicz, Iwan Pietrowicz, Jurek Pawłowski, Grzegorz Pawłowicz, Piotr Ilicz, Wasyl Fedorowicz, Fiodor Zubrycki, Wasyl Grygorowicz, Andrzej Stefanowicz, Jan Mikołajewicz. Собрание древних грамот и актов городов Минской губернии, нр. 62, с. 106.

20 Собрание древних грамот и актов городов Минской губернии, нр. 62, c. 104-107.

21 Wojewoda miński Piotr Tyszkiewicz obwiniał prawosławnych skupionych przy cerkwi św. św. Piotra i Pawła o czynienie buntów, skutkiem czego miało być brak wiernych w cerkwi zamkowej Narodzenia NMP. Собрание древних грамот и актов городов Минской губернии, нр. 73 , c. $130-132$
}

o budowanie szkół na gruntach szlacheckich i o czynienie „przeszkód” szkołom unickim przez diaków brackich, którzy nauczali w szkole brackiej. 15 stycznia 1620 roku bractwo otrzymało wezwanie na sąd królewski ${ }^{22}$. Szlachta mińska oprotestowała wezwanie mieszczan na sąd, bowiem to ona była fundatorem i cerkwi i monasteru i szkoły na placach, które sama ufundowała. Przedstawiciele szlachty mińskiej słusznie zauważyli w swym liście, że metropolita unicki Józef Rutski, wykorzystując sejm i inne instytucje państwowe, starał się wykorzenić wiarę prawosławną23. Osłabieniu monasteru i bractwa miały też służyć pozwy do sądów o zwrot majątku monasterskiego. Przykładem może być skarga złożona w 1630 roku przez unitów odnośnie majątku Perespa. Mimo, że został on ufundowany przez sędziego ziemskiego Wołodkiewicza w 1623 roku na poczet monasteru św. św. Piotra i Pawła i bractwa przy nim działającego, ihumen unickiego monasteru Wniebowstąpienia Pańskiego w Mińsku Aleksander Szkołdycki zarzucał prawosławnym mnichom, że wykorzystują folwark bezprawnie i nie chcą go zwrócić metropolicie Rutskiemu, ani nie chcą płacić zadośćuczynienia w wysokości 400 kop groszy litewskich ${ }^{24}$. 1 kwietnia 1620 roku Hilarion Baranowicz wniósł nową skargę na bractwo i na „дъяки школные которых прынцыпалове новое церкви (...) своим коштомъ при школе и церкви ховают”. Тут razem nauczyciele braccy przewinili się tym, że przyjęli księdza Teodora Jermolicza, który porzucił unitów i znalazł schronienie w bractwie (bursie). Unitom udało się pojmać księdza Jermolicza. Gdy był on siłą prowadzony do unickiego monasteru, nauczyciele braccy oswobodzili go i ponownie dali schronienienie w domu brackim ${ }^{25}$.

W 1620 roku, z błogosławieństwa patriarchy jerozolimskiego Teofana III zostało utworzone w Mińsku bractwa młodzieżowe, którego trzon stanowili uczniowie szkoły brackiej ${ }^{26}$. Działalność bractw młodzieżowych opierała się o statut wzorowany na regulaminie bractw „starszych” i błogosławieństwie patriarchy bądź metropolity. Pracę organizacji nadzorował opiekun duchowy i 2 członków bractwa "starszego".

22 Собрание древних грамот и актов городов Минской губернии, нр. 74 , c. $132-134$

23 Podpisy pod protestacją złożyli: Teodor Stetkiewicz, Jerzy Skumin Tyszkiewicz wojski województwa mińskiego, Constanty Ratomski, Adam Wańkowicz, Jan Kisiel Dorohynickiy, Jan Stetkiewicz, Włodzimierz Pietraszewicz, Piotr Przybytek, Bazyli Chodyczyński. Собрание древних грамот и актов городов Минской губернии, нр. 75, с. 134135.; К. Харламповичъ, Западнорусскія православныя школьл... , c. 336 .

24 Собрание древних грамот и актов городов Минской губернии, нр. 90, c. 164-165.

25 Собрание древних грамот и актов городов Минской губернии, нр. 77. W dokumencie wśród szlachty - fundatorów cerkwi brackiej wymienia się: Iwana Paszkiewicza Piłatyka, Iwana Jachimowicza Orlika, Andrzeja Artemowicza Szyszkę - burmistrzów mińskich; Daniela Artemowicza i Wasila Bohusewicza - rajców miejskich; Fiodora Szyszkę - starszego bractwa mińskiego. К. Харламповичъ, Западнорусскія православныя иколь ..., с. 337.

26 Udzielając błogosławieństwa patriarcha jerozolimski Teofan III określił reguły funkcjonowania bractwa młodzieżowego: „братство въ вьрь благо и неколебинмо стояти и чину старьйшаго братства, паче же прочихъ древньйшихъ братств”. АЗР, т. IV, нр. 220, с. 509-510. 
Przy monasterze św. św. Piotra i Pawła od XVII wieku działało również bractwo miodowe św. Anny. Syciło ono trzy razy do roku miód (Wielkanoc, Zaśnięcie NMP, Boże Narodzenie) ${ }^{27}$. W 1635 roku otrzymało ono dwa place od Anny Stetkiewiczowej ${ }^{28}$. Bractwo to prowadziło szpital ulokowany naprzeciwko cerkwi św. św. Piotra i Pawła, w domu otrzymanym od Reginy Ogińskiej podkomorzyny trockiej w 1635 roku $^{29}$.

Nie przetrwały dokumenty dotyczące szkoły w Mińsku z następnych kilkunastu lat jej funkcjonowania. Pojawiała się ona jednak w zapisach testamentowych: w 1634 roku Mikołaj Derewojed przeznaczył na uposażenie cerkwi brackiej 40 kop groszy, „и на выховане попом трыдцат копь гршеи". Nowym elementem w testamencie jest dyspozycja pewnej kwoty z przeznaczeniem na wykształcenie duchownego ${ }^{30}$. Wiemy, że 18 marca 1633 roku król Władysław IV nadał przywilej potwierdzający funkcjonowanie szkoły przy bractwie św. św. Piotra i Pawła ${ }^{31}$.

Aktywnie działało również bractwo prawosławne w Mińsku, w oparciu o przywilej Władysława IV z dnia 18 marca 1633 roku. Król zezwalał na organizowanie brackich zebrań, działalność szkół i drukarni, w których bractwo ponosiłoby koszt zatrudnianych pracowników stanu świeckiego lub duchownego, prowadzenie przytułku dla biednych i chorych. Bractwo samodzielnie mogło zarządzać swym majątkiem ruchomym i nieruchomym pozyskiwanym w drodze darowizn i zapisów. Nieruchomości były zwolnione od podatku ${ }^{32}$.

Anna Stetkiewicz, podkomorzyna brasławska, w 1635 roku ufundowała monaster w Pryłukach, nadając mu fundusz składający się ze wsi Sniekoczycy i 5000 kop groszy. Opiekę nad monasterem miał sprawować jej syn Bogdan Statkiewicz bądź bractwo św. Piotra i Pawła w Mińsku, gdyby nikt z rodziny nie został wierny prawosławiu ${ }^{33}$.

W Mińsku, wcześniej niż w innych miastach, katolicy i unici doprowadzili do wydania przez króla Władysława IV w 1635 roku dekretu odnośnie składu rady miejskiej. Zarzucali oni prawosławnym w radzie miejskiej, iż „z rady ich wyłączywszy, onych więcey nie przypuszczacie y nie obieracie, ale tęz wszystke Rade Burmistrzow, Raycow y Lawnikow, ludzmi swey Religiey Graeckiey, posłuszeństwu Pasterza powszechnego przeciwnemi zasadziliscie. A nadto ieszcze rozne nasmiewiska y pochwałki na Pasterzow ich, onych samych, Religią ich urągając y

\footnotetext{
27 W 1679 roku król Jan III Sobieski potwierdził przywilej na sycenie miodu trzy razy w roku. Uzyskane przychody ,świecami winem tąż cerkiew opatrywało", Собрание древних грамот и актов городов Минской губернии, нр 148, с. 131-133.

28 LVIA, f. 610, nr 3, 369, k. 2. W 1646 roku zapis Anny Stetkiewiczowej potwierdził Krzysztof Stetkiewicz, tamże.

${ }^{29}$ LVIA, f. 610, nr 3, 369, k. 2. W 1643 roku mieszczanin miński Grzegorz Sawicz ustanowił fundusz na szpital, składający się z domu, placu i dwóch browarów nad rzeką Swisłocz, tamże.

30 Собраніе древнихъ грамотъ и актовъ городовъ минской губерніи, нp. 96 , с. 179

31 АВАК, т. XI, нр. 36, с. 101-104.

32 Собраніе древнихъ грамоть и актовъ городовъ минской губерніи православныхъ монастырей иерквей и по разнымъ предмљтамъ, Минскъ 1848, нр. 123, с. 250-253; А. Папков, Братства..., с. 178.

33 Минская Старина, вып. IV, нр. 52, с. 16-17.
}

derogując, czynicie"34. Władysław IV przekazał miejsca w radzie miejskiej katolikom i unitom. Decyzja monarchy została oprotestowana i nie weszła w życie, co potwierdza chociażby skarga unitów z 1665 roku o pobicie wymierzona była przeciwko prawosławnym członkom magistra$\mathrm{tu}^{35}$. O rosnących prześladowaniach ze strony katolików i unitów, wykorzystujących władzę świecką pisał w liście z 2 kwietnia 1640 roku do bractwa mińskiego metropolita Piotr Mohyła. Zwrócił on również uwagę na zaplanowane ataki na szkoły brackie. Uczniowie tych szkół „внауках оразъ и въры Стой боронити и цвичится позазрели тому на око маючи науки ижъ латво выучившысия могут правду всему свђту показати и церковъ Стую моцно боронити". Stosowaną metodą straszenia uczniów prawosławnych było oskarżanie ich o przewinienia, których nie uczynili. Miało to doprowadzić do porzucenia przez nich nauki ${ }^{36}$.

W drugiej połowie XVII wieku wzmocniła się kondycja finansowa konfraterni przy monasterze św. św. Piotra i Pawła poprzez liczne darowizny i zapisy testamentowe ${ }^{37}$. W 1685 roku Klemens Tryzna, ihumen wileńskiego monasteru św. Ducha, podjął decyzję o przekazaniu pod opiekę brackiemu klasztorowi mińskiemu monasteru w Sielcach. Odbyło się to za zgodą synów fundatorów - Michała i Manuela Tyszkiewiczów ${ }^{38}$. Autorytet prawosławnej konfraterni w Mińsku, dzięki współpracy z innymi bractwami, rósł. W drugiej połowie XVII wieku bractwo przedsięwzięło kroki w celu uniezależnienia się od wileńskiego bractwa św. Ducha, jednak postawa metropolity kijowskiego Warłaama Jasińskiego i archimandryty monasteru brackiego w Wilnie Piotra Tołokańskiego nie dopuściły do tego ${ }^{39}$. Zaistniały konflikt ujawnił, że w Mińsku działało kilka bractw. Oprócz bractwa skupionego przy monasterze św. św. Piotra i Pawła istniały: „Sgo Jana Krzciciela Młodziencze, tudzież Swiętych Michała i Mikołaia"40.

W 1670 roku bractwo gościło greckiego metropolitę macedońskiego Sofroniusza Heleponosa. „Greczyn swięcił mnostwo Ludzi na Kapłanstwo, chłopów prostych nieuków, cos szepcąc po Grecku nad nimi”. Czy metropolita grecki wyświęcał absolwentów szkoły brackiej? Unici potraktowali Greka jako szpiega tureckiego i z tego powodu

\footnotetext{
34 Собрание древних грамот и актов городов Минской губернии, нр. 103 , с. $198-200$

35 Собрание древних грамот и актов городов Минской губернии, нр. 137, с. $294-296$.

36 Собраніе древнихъ грамотъ и актовъ городовъ минской губерніи православныхъ монастьрей иерквей и по разнымъ предмътамъ, Минскъ 1848, нр. 112, с. 223-227.

37 Zapisy na rzecz monasteru św.św. Piotra i Pawła i bractwa poczynili m.in.: Adam Wańkowicz, Собрание древних грамот и актов городов Минской губернии, нр 10, с. 198-200; Mikołaj Derewojed, tamże, нр 96, c. 170-175; ihumenia Eugenia Szembelówna,tamże , нp 106, c. 212-216; Krzysztof Kiszka, wojewoda witebski, tamże, нp 118 , с. 237-239.

38 Собрание древних грамот и актов городов Минской губернии, нр 151, с. 346-349.

39 Собрание древних грамот и актов городов Минской губернии, нр 154, с. 353-357.

40 Tamże.
} 
na wniosek metropolity unickiego Gabriela Kolendy bractwo zostało wezwane na sąd asesorski ${ }^{41}$.

Prześladowania ze strony unitów i katolików w Mińsku nasiliły się w końcu XVII wieku. W 1691 roku do monasteru św. św. Piotra i Pawła siłą wdarł się unicki pleban Sałgan Jurewicz z gromadą katolików i unitów chcąc prawosławnych mnichów nawrócić na unię. Bracia wraz z archimandrytą Piotrem Paszkiewiczem trzy doby odpierali przeciwników wykorzystując do obrony broń i kamienie ${ }^{42}$. W 1722 roku monaster zaatakował z uzbrojonymi ludźmi szlachcic Michał Gliński, którego mnisi oskarżyli o „bicie, kaleczenie, rąbanie zakonników"43. W 1734 roku zanotowano kolejny napad szlachty województwa mińskiego z bezczeszczeniem świątyni: „въЂхали въ церковь на лошадяхъ (...), на алтарь великій из огненнаго ручнаго ружья стрьляли (...), священниковъ и монаховъ жестоко тирански и немилосердно съкли, рубили полосами и прикладами, свђщами горящими глаза жгли"44.

W dokumentach źródłowych traktujących o bractwie i jego monasterze z począwszy od końca XVII wieku nie znajdujemy żadnej wzmianki ani na temat szkoły, ani na temat uczniów, ani na temat nauczycieli. Świadczyć to może o tym, że wysiłki unitów i katolików doprowadziły do zamknięcia tej brackiej placówki.

$\mathrm{Na}$ pogarszający się stan monasteru wpływ miały również spory wewnętrzne między bractwem i kolejnymi ihumenami. Ci ostatni nie dbali o klasztor i trwonili jego majątek. Dopiero ihumen Nikodem Tomiłowicz, skierowany przez archimandrytę monasteru św. Ducha do Mińska z klasztoru w Jewiu, przywrócił porządek w monasterze. Doprowadził on do wzrostu powołań, do zwrotu części zrabowanego majątku. Tomiłowicz reaktywował także działalność szkoły dla dzieci ${ }^{45}$. Odwołanie ihumena Niko-

\footnotetext{
41 Przed sąd assesorski zostali zawezwani: namiestnik klasztoru św. św. Piotra i Pawła o. Ihnat Zygmuntowicz członkowie mińskiej ławicy dyzunickiej: Aleksander Żytkiewicz, lentwójt; Paweł Jelisiejewicz, rajca; Michał Szyszko burmistrz; Mateusz Balcerowicz, burmistrz; Włas Zienowicz, ławnik; członkowie bractwa: Aleksander Olisiejewicz, Daniel Olisiejewicz, Stefan Raszkiewicz, Eumeni Piotrowicz. Собрание древних грамот и актов городов Минской губернии, нр 140 , с. 308-309; нр 141, с. $309-310$.

42 Баравой Р. В., Агляд гісторыі мінскага свята-петра-паўлаўскага сабора і манастыра, с. 193. Tо zdarzenie w swoim dzienniku opisał św. Dymitr Rostowski. И. Чистович, Очерк Истории Западно- Русской Церкви, ч. II, Санкт Петербург 1884, с. 179.

$43 A B A K$, т. XI, нp. 137, c. 429. Wyrokiem Trybunału Litewskiego Michał Gliński i jego towarzysze zostali skazani na śmierć. Za wstawiennictwem Jerzego Glińskiego, ojca skazanego, doszło do ugody w wyniku której za wycofanie skargi mnisi monasteru św. św. Piotra i Pawła uzyskali kwotę 1200 złotych polskich.

44 АСД, т. 11, нр 86, с. 120-121; И. Чистович, Очерк Истории Западно- Русской Церкви, Санкт Петерсбург 1882, с. 179.

45 А. Папков, Братства..., с. 266.
}

dema przez archimandrytę brackiego monasteru w Wilnie Bogdanowicza skutkowało ponownym upadkiem morali w monasterze. 30 sierpnia 1748 roku bractwo skierowało do Świętego Synodu skargę na postanowienia Bogdanowicza. Zapisano w niej: „он опустошил монастырь (...) ни однаго монаха ни осталось. (...) Школа уничтожена; чрез весъ великій пость преждеосвященной литургіи не было; люди безъ исповъди и крещенія умираютъ; а не малая часть людей уходить къ иным вЊрамъ"46. Mimo starań bractwa i samego ihumena decyzją Świętego Synodu Tomiłowicz został skierowany do monasteru w Wiatce.

Kolejni ihumeni przyczyniali się do pogorszenia stanu monasteru. W liście z 12 kwietnia 1751 roku Sylwester Dobrynia informował metropolitę kijowskiego Tymoteusza Szczerbackiego o tym, że monastery podległe klasztorowi wileńskiemu św. Ducha stawały się puste i zniszczone. Szczególnie odnosiło się to do sytuacji, w jakiej znalazł się monaster św. św. Piotra i Pawła w Mińsku, z uwagi na podupadłe morale ihumenów Pawła Stefanowicza i Arseniusza Tomiłowicza. Konsekwencją pijaństwa mnichów było zrujnowanie za długi monasteru sieleckiego i sołomareckiego ${ }^{47}$.

Sytuacja prawosławnych w Mińsku w drugiej połowie XVIII wieku, kiedy mnisi oficjalnie nie mogli sprawować swej posługi duszpasterskiej, stała się nie do zniesienia. Podobnie jak w innych miastach Wielkiego Księstwa Litewskiego byli oni napadani, gdy chcieli dokonać ostatniego namaszczenia $\mathrm{w}$ domu chorego lub podczas pogrzebu. Katolicy nie dopuszczali również do udzielenia sakramentu małżeństwa w cerkwi ${ }^{48}$.

Mimo, że bractwo z przeszkodami funkcjonowało do 1795 roku, szkoły w drugiej połowie XVIII wieku nie udało się utrzymać.

46 И. Чистович, Очерк Истории Западно- Русской Церкви, с. 181.

47 Чтения в историческом обществе Нестора летописиа, кн. IX, отд. III, Киев 1895, с. 19-20. Tak Sylwester Dobrynia opisał postępowanie ihumena Arseniusza Tomiłowicza: „O powodzeniu x. Arseniego posetnie donaszam, że wcale iuż zgubił klasztor, y iezeli W. P. D. na dyspozycye klasztoru Minskiego nie przyszlesz zakonnika iakiego, a onego nie weźmiesz, to nie tylko na wiosne, ale barzo iuż y teraz mało co i teraz iest w folwarkach y klastorze Sieleckim y Perespie zboża, bo gdyż ustawicznie żydom każe młócić zboże, a sam wyciśczywszy wszystko y przedawszy klasztor Sielecki, ma wyjechać na mundrowkę z Gabryielem sekretarzem swoim. Tamże, c. 22.

48 И. Чистович, Очерк Истории Западно-Русской Церкви, с. 182. Ostatecznie doszło do kompromisu między prawosławnymi, a katolikami w myśl którego prawosławnym pozwolono swobodnie odprawiać sakramenty pod warunkiem, że prawosławni nie będą się przeciwstawiać konwersjom z prawosławia na katolicyzm i nie pozwolą przyjmować wiary prawosławnej tym, których jeden z rodziców był katolikiem. 


\section{Bibliografia}

\section{Źródła rękopiśmenne}

Lietuvos valstybès istorijos archyvas, f. 610, nr 3, 369, k. 1, k 3-3v; f. 610, nr 3, 369, k. 2.

\section{Źródla drukowane}

Акты издаваемые Виленской археографической комиссией для разбора древних актов, т. ХІ, Вильна 1880.

Акты относящиеся к истории Западной России, т. IV, Санкт Петербург 1851.

Археографический сборник документов, относящихся кистории Северо-Западной Руси / Изд. при Управлении Виленского учебного округа, т. XI, Вильна 1890.

Собрание древних грамот и актов городов Минской губернии православных монастырей, иерквей и по разным предметам, Минск 1848.

Чтения в историческом обществе Нестора летописиа, кн. IX, отд. III, Киев 1895.

\section{Literatura:}

Баравой Р. В., Агляд гісторыі мінскага свята-петра-паўлайскага сабора і манастыра ( XVII - пачатак XX cmcm.), [в:] Верныя веры баџькой, Мінск 2013.

Баравой Р. В., Менскія цеерквы, [в:] Вялікае княства Літойскае. Эниіклапедыл, Т. 2, Мінск 2006.

Мещеряков В.П., Братские школь Белорссии (XVI - первая половина ХVII в.), Минск 1977.

Мікульскі Ю. М., Гісторыя іконы Божай Маці Менскай (да XVIII cm.), „Беларуская даўніна”, Мінск 2014.

Папков А., Очерк истории западно-русских православных братств, Свято-Троицкая Сергиева лавра 1900.

Сарока Ф. А., Пра рэставрацыю насиенных роспісай, [в:] Beрныл веры бацькоў, Мінск 2013.

Харламповичъ К., Западнорусскія православныл школь ХVI и начала ХVII века, Казанъ 1898.

Чистович И., Очерк Истории Западно- Русской Церкви, Санкт Петербург 1882.

Rozmiar artykułu: 0,8 arkusza wydawniczego 


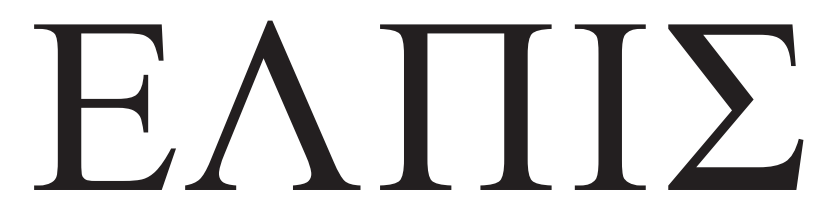

CZASOPISMO TEOLOGICZNE KATEDRY TEOLOGII PRAWOSŁAWNEJ UNIWERSYTETU W BIAŁYMSTOKU

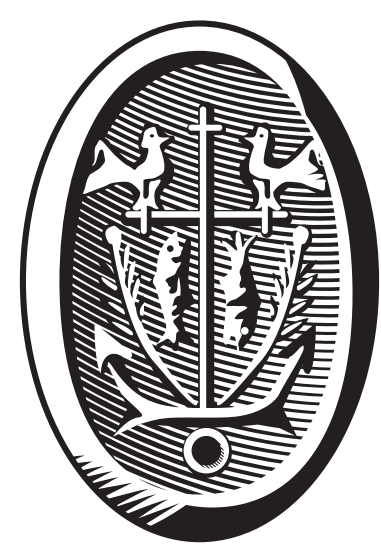

ADRES REDAKCJI

ul. Ludwika Zamenhofa 15, 15-435 Białystok, Polska tel. 85 745-77-80, e-mail: elpis@uwb.edu.pl www.elpis.uwb.edu.pl 